\title{
DISCURSO DO MINISTRO DA SAÚDE NA SOLENIDADE DE ABERTURA DO XXVIII CONGRESSO BRASILEIRO DE ENFERMAGEM E I CONGRESSO SUL-AMERICANO DO CICIAMS
}

O Chefe da Nação, o Exmo. Sr. Presidente Ernesto Geisel honrou-me com a incumbência de representá-lo nesta cerimônia, exprimindo assim o alto apreço do Governo Brasileiro pela nobre profissão do enfermeiro.

Profissão que ao lado do preparo técnico requer de modo muito especial qualidades humanas das mais nobres, dedicação sem limites, disciplina permanente e fidelidade irrestrita a princípios éticos que fazem a grandeza da profissão.

Os organizadores e participantes deste conclave aqui se reúnem para discutir o aprimoramento dos serviços que prestam à coletividade. Isto os credencia à admiração e gratidão de todos nós.

E fato conhecido a carência de profissionais de enfermagem no Brasil como em todo mundo.

As limitações quantitativas e qualitativas do sistema formador e as limitações econômico-financeiras do mercado de trabalho podem ser apontadas como as causas principais daquela carência.

$\mathrm{E}$, se no que se concerne à Medicina, Odontologia e Farmácia o Brasil já possa esperar atingir até 1980 as metas definidas na última conferência internacional dos Ministros de Saúde das Américas, tudo indica que, no final da década ainda haverá um deficit de 38.600 enfermeiros.

Desde 1974, o Governo do Presidente Geisel vem desenvolvendo esforços concentrados para minorar aquele deficit. $O$ Ministério da Educação e Cultura já criou 11 novos cursos de enfermagem, surgindo mais 500 vagas, de preferência em regiões ainda carentes. Foi criado um centro de pós-graduação na Universidade Federal do Rio de Janeiro. desenvolvendo-se assim um trabalho sólido para a capacitação de docentes.

Esforços se desenvolvem também para suprir a deficiência de livros didáticos bem como para a elevação do nível dos cursos existentes. O Ministério do Trabalho instalou o Conselho Federal de Enfermagem. O INPS, com o crescimento acelerado de sua rede de serviços próprios e contratados, vai ampliando dia a dia o mercado de trabalho. O Ministério da Saúde construiu a Escola de Enfermagem de Manaus e está equiparando-a para ser um Centro Latino-Americano de Enfer- 
magem Tropical. Ao mesmo tempo, elabora a carreira de Sanitaristas onde novas e grandes oportunidades serão oferecidas aos enfermeiros de Saúde Pública. O Conselho de Desenvolvimentio Social, integrando a ação daquelas Pastas, criou ainda o Fundo de Apoio ao Desenvolvimento Social, que somente em 1975 aprovou projetos no valor de 1,5 bilhões de cruzeiros para o financiamento de construção ou ampliação de hospitais, criando novos empregos. O Plano de Classificação de Cargos melhorou substancialmente a remuneração do pessoal de enfermagem.

Existe assim, de parte do Governo, uma preocupação real, demonstrada exuberantemente por fatos objetivos, preocupação no sentido de reduzir as deficiências existentes.

A ação do Governo não se limitou à ampliação da capacidade de formação de pessoal de enfermagem em todos os níveis, mas foi além, promovendo a expansão do mercado de trabalho e a melhor remuneração para que a profissão se tornasse mais atrativa.

Hoje, cursos de enfermagem que contavam numerosas vagas não ocupadas por falta de demanda, estão com a sua lotação completa.

Já se pode prever que em 1980 o deficit não será tão grande como se esperava.

Estreita-se e consolida-se dia a dia a integração dos programas do Ministério da Saúde com o INPS, da Saúde com a Educação, da Saúde com o Trabalho. Ainda há um longo caminho a cumprir, mas, pelo menos a partida já foi dada.

Ainda resta estudar a possibilidade de se processar uma formação menos elitista e mais adequada às possibilidades do atual mercado de trabalho. O preparo de pessoal de nível intermédio ainda requer aprimoramento. E também justificável a discussão das condições de trabalho.

Estes e outros assuntos merecerão certamente a atenção desta reunião propiciando pareceres e conclusões que serão apreciados com atenção pelos órgãos competentes do Governo que não prescinde da colaboração de todos.

Estou certo que ao lado do ensino de enfermagem irá preocuparlhes também a educação para o exercício da enfermagem. $O$ verdadeiro enfermeiro é antes de tudo o fruto do aprimoramento das mais belas qualidades do homem, um exemplo de solidariedade e de ética profissional.

Em todas as profissões relacionadas com a saúde, urge lembrar que o relacionamento profissional-paciente, o respeito pela dignidade a pessoa humana, a reverência ante a própria dignidade profissional, os eternos valores morais são pelo menos tão importantes quanto os conhecimentos técnicos-científicos.

Com os mais afetuosos sentimentos desejo-lhes um trabalho proficuo com o pensamento voltado para a melhoria da Saúde do Homem Brasileiro. 